Ann. Biol. anim. Bioch. Biophys., I973, 13 (3), 399-4I8.

\title{
EFFETS COMPARÉS DE RESTRICTIONS PROTÉIQUES ET DE RESTRICTIONS ÉNERGÉTIQUES SUR LES CONTENUS EN PROTÉINES ET EN ACIDES NUCLEIQUES DES TISSUS DU RAT EN CROISSANCE
}

\author{
G. DURAND \\ avec la collaboration technique de Noêlle Bourgeaux \\ Station de Recherches de Nutrition, \\ Centre national de Recherches zootechniques, I, N.R. A., \\ 78350 Jouy en Josas
}

\section{RÉSUMÉ}

Des lots de Rats mâles sevrés depuis une semaine et pesant à jeun $70 \mathrm{~g} \pm 3 \mathrm{~g}$ sont soumis à des restrictions, soit de l'apport protéique, soit de l'apport énergétique de la ration; ils sont comparés à un lot témoin recevant ad libitum un régime équilibré contenant $\mathrm{r} 6 \mathrm{p}$. roo de protéines. Tous les lots sont sacrifiés lorsque leur poids vif moyen à jeun atteint $200 \mathrm{~g}$.

Les rations distribuées aux lots restreints, en protéines d'une part, en énergie d'autre part, sont ajustées de façon que ces lots présentent, deux par deux, une vitesse de croissance moyenne identique $\left(\frac{\mathrm{V}}{2}\right.$ et $\frac{\mathrm{V}}{3}, \mathrm{~V}$ étant la vitesse de croissance moyenne des témoins).

Le corps des animaux est disséqué en six fractions : musculature des membres postérieurs ; foie ; peau ; tissus adipeux ; viscères ; carcasse (musculature + squelette). Le poids frais, ainsi que les contenus en protéines, DNA et RNA de ces six parties corporelles sont mesurés. Ces mesures permettent en particulier d'évaluer le nombre et la taille des cellules.

Les résultats montrent que les effets cle l'un et l'autre type de restriction sont très variables suivant la fraction corporelle et le critère considéré. On peut cependant détacher quelques points particuliers :

- Poids frais : La restriction protéique favorise le tissu adipeux, tandis que la restriction énergétique favorise la musculature et les viscères.

- Contenu protéique: La restriction protéique favorise le tissu adipeux ; la restriction énergétique favorise la musculature, la peau, les viscères et la carcasse.

- Contenu en DNA : Hormis les tissus adipeux, la restriction protéique défavorise toutes les fractions, et surtout la peau; la restriction énergétique défavorise toutes les fractions, surtout le foie et les tissus adipeux.

- Contenu en RNA : La restriction protéique diminue en général fortement le contenu en RNA des différentes fractions, sauf celui des tissus adipeux qu'elle accroît; la restriction énergétique augmente le contenu dans la peau et les viscères. 


\section{INTRODUCTION}

Les sous-alimentations protéique et énergétique ont donné lieu, au cours de la première moitié du siècle, à des recherches étiologiques et cliniques d'où sont issus les termes de Kwashiorkor et de marasme ; puis sont venues des recherches biochimiques et histologiques fondées sur l'expérimentation animale, dont un grand nombre a fait l'objet d'une revue par PLATT et coll. (I964). Des travaux récents sont consacrés à l'étude de la cellularité (prolifération cellulaire, taille des cellules, contenus cellulaires) de divers tissus ou organes d'animaux soumis soit à une restriction protéique (MENDEs et WATERLow, I958 ; STRUNZ et I,ENkEIT, I963; DuRAND et coll., I966; HowARTH, I972), soit à une restriction énergétique (WINICK et NoBLE, I966 ; Durand et coll., r967-r968 ; DURAND et PENOT, r969 b, r970; Graystone et ChEEK, I969; ELLIOTT et CHEEK, I968). La comparaison des effets de l'un et l'autre type de restriction a été effectuée par HILL et coll. (I970) dans le muscle et le foie du Rat sevré. Ces auteurs comparent à des témoins normaux, d'une part des Rats restreints en protéines mais recevant des calories en quantité convenable eu égard à leur poids vif, d'autre part des Rats restreints en calories mais recevant assez de protéines eu égard à leur poids vif. Dans ce travail, les animaux sont sacrifiés et comparés à âge égal, mais à poids vif très différent.

Le présent travail utilise également le Rat sevré ; il se propose de comparer les effets de restrictions plus ou moins sévères, soit protéiques, soit énergétiques, sur la cellularité du foie, des principaux tissus (muscle, peau, dépôts adipeux) et de fractions corporelles comme les viscères et la carcasse. Les rations alimentaires sont aménagées de façon qu'à un lot restreint protéique corresponde un lot restreint calorique présentant la même vitesse de croissance. Les effets de la restriction sont donc comparés simultanément à âge et à poids égaux.

Pour chaque fraction étudiée, sont mesurés : le poids frais ; le contenu en acide désoxyribonucléique (DNA), proportionnel au nombre de cellules; le contenu en acide ribonucléique (RNA). Les valeurs des rapports poids frais : DNA, protéines : DNA, RNA : DNA permettent d'apprécier respectivement les variations de la taille des cellules, de leur contenu en protéines et en RNA.

\section{MA'TÉRIEL, ET MÉTHODES}

\section{A. - Matériel animal (fig. I, tabl. I et 2)}

Six lots de ro à 20 Rats mâles Wistar âgés de 30 jours, pesant à jeun $70 \mathrm{~g} \pm 2 \mathrm{~g}$, sont utilisés.

- Un premier lot est sacrifié à ce stade et constitue le lot témoin $70 \mathrm{~g}(\mathrm{~T} 7 \mathrm{o})$.

- Un deuxième lot reçoit ad libitum un régime équilibré contenant $\mathrm{i} 6 \mathrm{p}$. Ioo de protéines $(\mathrm{N} \times 6,25)$ apportées par de la farine de hareng de Norvège ; ce lot est sacrifié lorsque son poids à joun atteint $200 \mathrm{~g}$, et constitue le lot témoin $200 \mathrm{~g}$ ( $\mathrm{T} 200$ ). Il passe de $70 \mathrm{~g}$ à $200 \mathrm{~g}$ en 22 jours, soit une vitesse de croissance moyenne de $6 \mathrm{~g} / \mathrm{jour}$.

— Le troisième et le quatrième lot reçoivent des régimes appauvris en protéines, de façon 
que leur vitesse de croissance soit respectivement la moitié ( $3 \mathrm{~g} / \mathrm{jour}$ ) et le tiers ( $2 \mathrm{~g} / \mathrm{jour}$ ) de la vitesse de croissance du lot $\mathrm{T} 200$. Pour cela, on distribue des régimes contenant dans le premier cas, 8 p. Ioo de protéines (réduction protéique modérée $=\mathrm{RPM}$ ), dans le second cas $6 \mathrm{p}$. 100 de protéines (réduction protéique forte : RPF). Ces deux lots sont sacrifiés lorsque leur poids à jeun atteint $200 \mathrm{~g}$.

- Les cinquième et sixième lots reçoivent chaque jour une ration telle que les Rats disposent d'autant de protéines, minéraux et vitamines qu'en consommeraient des témoins de même poids; mais, dans cette ration, la quantité d'éléments énergétiques (glucides et lipides) est réduite de façon que les lots suivent des courbes de croissance linéaires correspondant respectivement à des vitesses de croissance de $3 \mathrm{~g} /$ jour et $2 \mathrm{~g}$ /jour. Pour cela, il faut, à poids égal d'animal, diminuer l'apport des éléments énergétiques de la ration de $45 \mathrm{p}$. Ioo dans le premier cas (réduction énergétique modérée : REM), de $55 \mathrm{p}$. Ioo dans le second cas (réduction énergétique forte : REF).

Comme les précédents, ces deux derniers lots sont sacrifiés lorsque leur poids moyen atteint $200 \mathrm{~g}$.

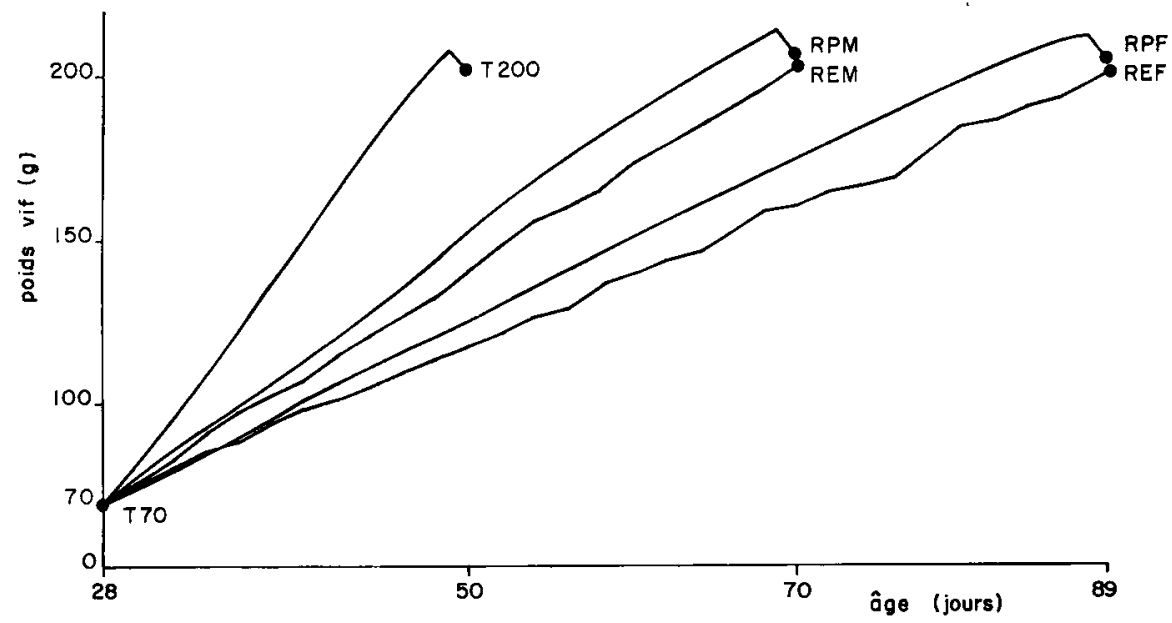

FIG. I. - Courbes de croissance des differents lots de Rats

Les animaux sont comparés à poids égal (200 g). ( $\mathrm{T} 200$ : témoins ; RPM : restriction protéique modérée ; REM : restriction énergétique modéré ; RPF : restriction protéique forte ; REF : restriction énergétique forte.)

TABLEAU I

Composition centésimale des régimes alimentaires distribués aux animaux

\begin{tabular}{|c|c|c|c|c|c|}
\hline & \multirow{2}{*}{ Témoins } & \multicolumn{2}{|c|}{ Réduction protéique } & \multicolumn{2}{|c|}{ Réduction énergétique } \\
\hline & & Modérée & Forte & Modérée & Forte \\
\hline $\begin{array}{l}\text { Farine de poisson }(g) \ldots \ldots \ldots \\
\text { DL-méthionine }(g) \ldots \ldots \ldots \\
\text { Huile d'arachide }(g) \ldots \ldots \ldots \\
\text { Sucre cristallisé }(g) \ldots \ldots \ldots \\
\text { Amidon de maïs }(g) \ldots \ldots \ldots \\
\text { Mélange minéral }(g) \ldots \ldots \ldots \\
\text { Mélange vitaminique } \ldots \ldots \\
\text { Agar-agar }(g) \ldots \ldots\end{array}$ & $\begin{array}{l}220 \\
1,6 \\
92 \\
220 \\
406,4 \\
30 \\
10 \\
20\end{array}$ & $\begin{array}{l}110 \\
0,8 \\
92 \\
220 \\
517,2 \\
30 \\
10 \\
20\end{array}$ & $\begin{array}{c}85 \\
0,5 \\
92 \\
220 \\
542,5 \\
30 \\
10 \\
20\end{array}$ & $\begin{array}{l}315 \\
2,3 \\
75 \\
180 \\
337,7 \\
45 \\
15 \\
30\end{array}$ & $\begin{array}{l}370 \\
2,7 \\
67 \\
161 \\
297,3 \\
51 \\
17 \\
34\end{array}$ \\
\hline & 1000 & 1000 & 1000 & 1000 & 1000 \\
\hline
\end{tabular}


Tous les animaux sont pesés chaque matin, avant la distribution de la ration quotidienne. La consommation alimentaire est mesurée.

Finalement les animaux des lots expérimentaux RPM et RPF d'une part, REM et REF d'autre part sont sacrifiés à âge et à poids égal; ils sont comparés à des témoins de même poids.

On considère comme étant à jeun les animaux auxquels la nourriture a été retirée I 5 heures avant le sacrifice. Les courbes de croissance sont portées sur la figure I et la composition des régimes alimentaires sur le tableau $\mathrm{I}$. Sur la figure $\mathrm{I}$, les écarts qui séparent les courbes de croissance des lots RPM et REM d'une part, et RPF et REF d'autre part, sont dus au fait que les animaux restreints en énergie, nourris chaque matin, consomment leur ration en quelques heures et sont ainsi toujours pesés à jeun.

Les consommations alimentaires, les vitesses de croissance et les indices de consommation figurent sur le tableau 2. Les animaux $\mathbf{T} 200$ présentent un gain de poids quotidien de 6 g/jour, avec un indice de consommation très satisfaisant de $2, \mathrm{I}$. Les animaux modérément et fortement restreints ont respectivement des croissances journalières voisines de $3 \mathrm{~g}$ et $2 \mathrm{~g}$. Dans les conditions expérimentales utilisées, l'appétit des Rats restreints n'est pas différent de celui des témoins.

Par ailleurs, on constate qu'à vitesse de croissance égale, l'indice de consommation (consommation alimentaire/gain de poids) est bien plus satisfaisant dans le cas de carence énergétique que de carence protéique : 2,8 contre 4,3 pour une croissance de $3 \mathrm{~g} /$ jour ; 3,6 contre 5,6 pour une croissance de $2 \mathrm{~g} / \mathrm{jour}$. Ceci est à rapprocher des résultats de HIIL et al. (1970).

TABLEAU 2

Vitesse de croissance et consommation alimentaire des lots expérimentaux

\begin{tabular}{|c|c|c|c|c|c|}
\hline & \multirow{2}{*}{$\begin{array}{c}\text { Témoins } \\
200 \mathrm{~g}\end{array}$} & \multicolumn{2}{|c|}{ Réduction protéique } & \multicolumn{2}{|c|}{ Réduction énergétique } \\
\hline & & Modérée & Forte & Modérée & Forte \\
\hline Nombre de rats & 10 & 10 & 20 & 16 & 10 \\
\hline Poids initial à jeun(g) (1)... & 70 & 71 & 69 & 70 & 71 \\
\hline Poids final $(g) \ldots \ldots \ldots \ldots$ & 209 & 211 & 207 & 201 & 200,5 \\
\hline Poids final à jeun (g) (2) ... & 202 & 203 & 200 & 201 & 200,5 \\
\hline Durée de l'expérience (j).... & 22 & 42 & 61 & 42 & 61 \\
\hline Gain de poids total $(\mathrm{g})(2-1)$ & 132 & 132 & 131 & 131 & 129,5 \\
\hline Gain de poids/j (g)........ & 6,00 & 3,14 & 2,15 & 3,12 & 2,12 \\
\hline Quantité d'aliment $/ \mathrm{i}$ (g MS). & 12,8 & 13,4 & 12,0 & 8,9 & 7,6 \\
\hline$\frac{\text { Quantité d'aliment }}{\text { Gain de poids }} \ldots \ldots \ldots$ & 2,1 & 4,3 & 5,6 & 2,8 & 3,6 \\
\hline
\end{tabular}

\section{B. - Sacrifice des animaux et prélèvement des tissus}

Chaque animal est saigné sous anesthésie à l'éther. Le sang est recueilli dans de l'azote liquide. Puis le corps est disséqué en six fractions distinctes :

- la peau ;

- les dépôts adipeux comprenant les dépôts sous-cutanés, périrénaux, épididymaires, mésentériques ;

- le foie ;

- les viscères, que l'on adjoint au sang;

- la musculature des membres postérieurs ;

-- le reste du corps, désigné sous le nom de "carcasse " et qui comprend principalement le squelette et la musculature (moins la musculature des membres postérieurs).

Chaque fraction est pesée et refroidie dans l'azote liquide. Pour chaque lot, on rassemble les fractions de même nature; on obtient ainsi six parties qui sont ensuite traitées et analysées.

Tous les traitements et méthodes analytiques qui permettent le dosage des protéines et acides nucléiques ont été précédemment décrites (DURAND et al., I969a). 


\section{RÉSULTATS}

Expression des résultats. - Dans tout le chapitre, les animaux sacrifiés à $200 \mathrm{~g}$ après avoir été soumis à des restrictions alimentaires, soit protéiques, soit énergétiques, sont comparés à des témoins de même poids.

Les quantités d'acides nucléiques sont exprimées en micromoles $(\mu \mathrm{Y})$ de bases. La conversion en microgrammes $(\mu \mathrm{g})$ de P-DNA et P-RNA se fait aisément en multipliant les chiffres par 3I, ou en mg de DNA ou RNA en les multipliant par o,33.

\section{A. - Muscles des membres postérieurs (tabl. 3)}

Il ressort tout d'abord de l'examen des tableaux 3 et 4 que, par rapport aux témoins, le poids frais des muscles des Rats restreints en protéines n'est pratiquement pas modifié, tandis qu'il est sensiblement augmenté ( +7 p. Ioo) chez les Rats restreints en énergie. L'intensité de la restriction ne se fait pas sentir.

Pour ce qui est du contenu total en protéines, la restriction protéique (RP) n'apporte pratiquement pas de changement, alors que la restriction énergétique (RE) exerce atu contraire une action favorable, renforcée par l'intensité de la restriction (de + I3 p. Ioo à + I8 p. Ioo).

Les deux types de restriction diminuent la quantité de DNA dans des proportions comparables, et d'autant plus que la restriction est plus forte $(-8$ p. Ioo à - I5 p. I00 environ).

La quantité de RNA est également diminuée dans tous les cas, mais contrairement au DNA, elle est marquée par le type de restriction (-2I p. roo pour RP ; - II p. Ioo pour RE), tandis que la sévérité de la restriction est sans effet particulier. Il apparaît par ailleurs que les deux types de restriction augmentent la taille moyenne des cellules (de +7 p. IOo à +2 I p. IOO) ; cette augmentation est plus forte dans le cas de la $\mathrm{RE}$ et de façon générale, elle est d'autant plus marquée que la restriction est plus sévère. Ces remarques sont également vérifiées pour les contenus cellulaires en protéines. Le rapport RNA/DNA est quelque peu amoindri par la RP, alors qu'il est maintenu à sa valeur normale en cas de RE.

$$
\text { B. - Foie (tabl. 4) }
$$

Les deux types de restriction alimentaire étudiés provoquent une diminution de la taille du foie. Cependant l'effet est plus marqué dans le cas de la réduction protéique $(-25 \mathrm{p}$. Ioo environ) que dans le cas de la réduction énergétique (- ro p. Ioo environ). Dans les conditions expérimentales utilisées, l'effet ne varie pas suivant le degré de restriction. Quant au contenu protéique des foies, s'il est amoindri dans le cas de RP ( -25 p. Ioo environ), il n'est qu'à peine diminué par la RE.

De même, la quantité de DNA est diminuée par les deux types de restriction alimentaire; mais, en contraste avec les faits relevés à propos du poids frais et du 
contenu protéique de l'organe, le DNA est plus sensible à la RE qu'à la RP (en moyenne $-23 \mathrm{p}$. Ioo contre - I $8 \mathrm{p}$. IOo).

Le RNA ne suit pas la même loi, puisqu'il est davantage touché par la RP. Il résulte de ces faits qu'il existe des différences très tranchées au plan du foie quant à la taille des callules et à leurs contenus en $A R N$ et en protéines, suivant le type de restriction appliquée : alors que les foies RP possèdent des cellules de taille normale ou très légèrement réduite, les foies $\mathrm{RE}$ possèdent des cellules de grande taille ( + I2 p. IOo). De plus, alors que les contenus en protéines et en RNA sont très près de la normale dans les callules RP, ces mêm es éléments sont augmentés dans les cellules RE ( + I3 p. IOO), à peu près dans les mêmes proportions que la taille des cellules.

\section{TABLEAU 3}

Muscle. - Effets comparés des restrictions protéiques et énergétiques sur diverses caractéristiques de la musculature des membres postérieurs, en particulier sur les contenus en protéines et en acides nucléiques

A. - Données exprimées en valeur absolue

\begin{tabular}{|c|c|c|c|c|c|c|}
\hline & $\mathrm{T} 70^{*}$ & $\mathrm{~T} 200^{*}$ & RPM * & $\mathrm{RPF} *$ & REM* & REF * \\
\hline $\begin{array}{l}\text { Poids frais }(g) \ldots \ldots \ldots \ldots \ldots \\
\text { Poids frais } / 100 \text { poids vif } \ldots \ldots \ldots \\
\text { Poids } \text { SD }(g) * * \ldots \ldots \ldots \ldots \\
\text { Poids SD } / 100 \text { poids frais } \ldots \ldots\end{array}$ & $\begin{array}{c}4,6 \\
6,7 \\
0,80 \\
17,5\end{array}$ & $\begin{array}{c}16,9 \\
8,4 \\
3,43 \\
20,3\end{array}$ & $\begin{array}{c}16,5 \\
8,1 \\
3,60 \\
21,8\end{array}$ & $\begin{array}{c}16,6 \\
8,3 \\
3,44 \\
20,7\end{array}$ & $\begin{array}{c}18,1 \\
9,0 \\
3,82 \\
21,1\end{array}$ & $\begin{array}{c}18,0 \\
9,0 \\
3,98 \\
22,1\end{array}$ \\
\hline $\begin{array}{l}\text { DNA/g SD ( } \mu \text { M-bases }) \ldots \ldots \ldots \\
\text { DNA total }(\mu M \text {-bases }) \ldots \ldots \ldots\end{array}$ & $\begin{array}{l}21,0 \\
16,8\end{array}$ & $\begin{array}{r}9,5 \\
32,6\end{array}$ & $\begin{array}{r}8,3 \\
29,9\end{array}$ & $\begin{array}{r}7,9 \\
27,2\end{array}$ & $\begin{array}{r}7,9 \\
30,2\end{array}$ & $\begin{array}{r}7,2 \\
28,6\end{array}$ \\
\hline $\begin{array}{l}\text { RNA/g SD }(\mu \mathrm{M} \text {-bases }) \ldots \ldots \ldots \\
\text { RNA total }(\mu \mathrm{M} \text {-bases }) \ldots \ldots \ldots\end{array}$ & $\begin{array}{l}33,6 \\
26,9\end{array}$ & $\begin{array}{l}17,2 \\
59,0\end{array}$ & $\begin{array}{l}12,8 \\
46,1\end{array}$ & $\begin{array}{l}13,6 \\
46,8\end{array}$ & $\begin{array}{l}13,6 \\
51,9\end{array}$ & $\begin{array}{l}13,2 \\
52,5\end{array}$ \\
\hline Protéines totales $(g) \ldots \ldots \ldots$ & 0,72 & 3,00 & 3,16 & 3,03 & 3,39 & 3,55 \\
\hline $\begin{array}{l}\text { Poids frais }(\mathrm{mg}) / \mathrm{DNA}(\mu \mathrm{M} \text {-bases) } \\
\text { Protéines }(\mathrm{mg}) / \mathrm{RNA}(\mu \mathrm{M} \text {-bases) } \\
\text { RNA/DNA } \ldots \ldots \ldots \ldots \ldots \ldots \ldots\end{array}$ & $\begin{array}{l}274 \\
42,9 \\
1,60\end{array}$ & $\begin{array}{l}518 \\
92,0 \\
1,81\end{array}$ & $\begin{array}{l}552 \\
105,8 \\
1,54\end{array}$ & $\begin{array}{l}610 \\
111,5 \\
1,72\end{array}$ & $\begin{array}{l}599 \\
112,2 \\
1,72\end{array}$ & $\begin{array}{l}629 \\
124,1 \\
1,83\end{array}$ \\
\hline
\end{tabular}

B. - Données exprimées en p. 100 du lot témoin $200 \mathrm{~g}$ ( $\mathrm{T} 200$ )

\begin{tabular}{|c|c|c|c|c|c|c|}
\hline & T 70 & $\mathrm{~T} 200$ & $\mathrm{RPM}$ & $\mathrm{RPF}$ & REM & REF \\
\hline Poids frais & 27,2 & 100 & 97,6 & 98,2 & 107,1 & 106,5 \\
\hline Protéines totales $\ldots \ldots \ldots \ldots \ldots$ & 24,0 & 100 & 105,3 & 101,0 & 113,0 & 118,3 \\
\hline DNA total............. & 51,5 & 100 & 91,7 & 83,4 & 92,6 & 87,7 \\
\hline RNA total............. & 45,6 & 100 & 78,1 & 79,3 & 88,0 & 89,0 \\
\hline
\end{tabular}

* T 70 : Témoin $70 \mathrm{~g}$; T 200 : Témoin $200 \mathrm{~g}$; RPM : Réduction protéique modérée ; RPF : Réduction protéique forte; REM : Réduction énergétique modérée; REF : Réduction énergétique forte. ** SD : Sec et dégraissé. 
TABIEAU 4

Foie. - Effets comparés des restrictions protéiques et énergétiques sur diverses caractéristiques du foie, en particulier sur les contenus en protéines et en acides nucléiques

A. - Données exprimées en valeur absolue

\begin{tabular}{|c|c|c|c|c|c|c|}
\hline & $\mathrm{T} 70^{*}$ & $\mathrm{~T} 200^{*}$ & $\mathrm{RPM} *$ & $\mathrm{RPF} *$ & REM * & REF * \\
\hline $\begin{array}{l}\text { Poids frais }(g) \ldots \ldots \ldots \ldots \ldots \\
\text { Poids frais } / 100 \text { poids vif } \ldots \ldots \ldots \\
\text { Poids } S D(g){ }^{* *} \ldots \ldots \ldots \ldots \ldots \ldots \\
\text { Poids } S D / 100 \text { poids frais } \ldots \ldots\end{array}$ & $\begin{array}{c}3,2 \\
4,6 \\
0,54 \\
17,0\end{array}$ & $\begin{array}{l}7,0 \\
3,5 \\
1,50 \\
21,4\end{array}$ & $\begin{array}{l}5,5 \\
2,7 \\
1,20 \\
21,9\end{array}$ & $\begin{array}{l}5,2 \\
2,6 \\
1,10 \\
21,2\end{array}$ & $\begin{array}{c}6,5 \\
3,2 \\
1,47 \\
22,6\end{array}$ & $\begin{array}{l}6,3 \\
3,1 \\
1,48 \\
23,5\end{array}$ \\
\hline $\begin{array}{l}\text { DNA/g SD }(\mu \mathrm{M} \text {-bases }) \ldots \ldots \ldots \\
\text { DNA total }(\mu \mathrm{M} \text {-bases }) \ldots \ldots \ldots\end{array}$ & $\begin{array}{l}45,7 \\
24,7\end{array}$ & $\begin{array}{l}40,9 \\
61,3\end{array}$ & $\begin{array}{l}41,4 \\
49,7\end{array}$ & $\begin{array}{l}45,8 \\
50,4\end{array}$ & $\begin{array}{l}32,7 \\
48,1\end{array}$ & $\begin{array}{l}31,4 \\
46,5\end{array}$ \\
\hline $\begin{array}{l}\text { RNA/g SD ( } \mu \text { M-bases) } \ldots \ldots \ldots \\
\text { RNA total }(\mu \mathrm{M} \text {-bases }) \ldots \ldots \ldots\end{array}$ & $\begin{array}{l}142 \\
76,5\end{array}$ & $\begin{array}{l}125 \\
188\end{array}$ & $\begin{array}{l}122 \\
146\end{array}$ & $\begin{array}{l}134 \\
148\end{array}$ & $\begin{array}{l}110 \\
162\end{array}$ & $\begin{array}{l}100 \\
148\end{array}$ \\
\hline Protéines totales (g) & 0,49 & 1,35 & 1,09 & 1,02 & 1,32 & 1,33 \\
\hline $\begin{array}{l}\text { Poids frais }(\mathrm{mg}) / \mathrm{DNA} \text { ( } \mu \text { M-bases) } \\
\text { Protéines (mg)/DNA ( } \mu \text { M-bases) } \\
\text { RNA/DNA } \ldots \ldots \ldots \ldots \ldots \ldots \ldots\end{array}$ & $\begin{array}{r}126 \\
19,8 \\
3,1\end{array}$ & $\begin{array}{l}114 \\
22,0 \\
3,06\end{array}$ & $\begin{array}{c}111 \\
22,0 \\
2,95\end{array}$ & $\begin{array}{c}103 \\
20,2 \\
2,92\end{array}$ & $\begin{array}{l}135 \\
27,5 \\
3,36\end{array}$ & $\begin{array}{l}135 \\
28,6 \\
3,18\end{array}$ \\
\hline
\end{tabular}

B. - Données exprimées en p. 100 du lot témoin $200 \mathrm{~g}$ (T 200)

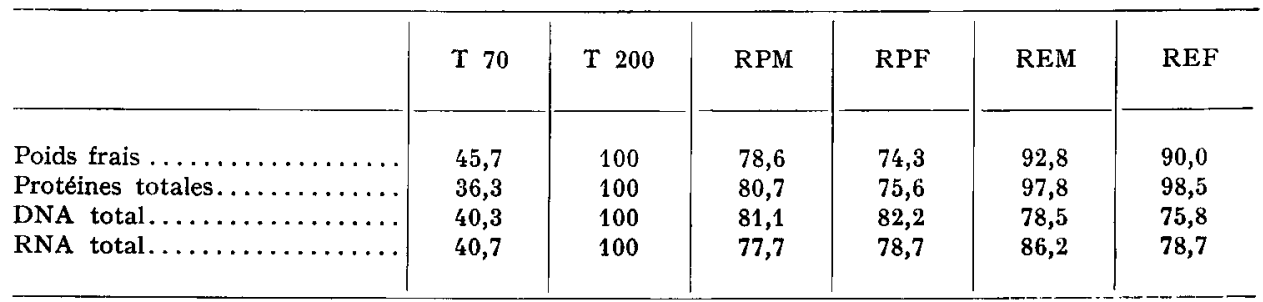

* T 70: témoin $70 \mathrm{~g} ; \mathrm{T} 200$ : Témoin $200 \mathrm{~g}$; RPM : Réduction protéique modérée ; RPF : Réduction protéique forte ; REM : Réduction énergétique modérée ; REF : Réduction énergétique forte.

** SD : Sec tt dégraissé.

\section{C. - Peau (tabl. 5)}

Les restrictions protéique et énergétique sont à peu près sans effet sur le poids frais de la peau : seulement peut-on noter une légère autgmentation due à la RE. Les effets différenciés des deux modes de restriction commencent toutefois de se faire sentir au plan du contenu en protéines, la RP manifestant un effet minorant (variant de -5 à - Io p. Ioo), et la RE un effet majorant (variant de +5 à + I2 p. I00).

Les deux modèles de restriction limitent l'un et l'autre la quantité d'ADN; cependant l'effet de la RP (-2I p. Ioo) est plus net que celui de la RE ( $-8 \mathrm{p}$. Ioo en moyenne). Pour le RNA, la disparité entre RP et RE est encore plus franche, car, si la première possède encore un effet restrictif (variant de $-I_{4} \grave{a}-23 \mathrm{p}$. Ioo), la seconde a un effet nul ou majorant ( + I2 $\mathrm{p}$. IOo). Il semble par ailleurs que les 
divers effets analysés s'accentuent, dans un sens ou dans l'autre, en même temps que s'accentue la sévérité des restrictions appliquées aux animaux.

Au niveau cellulaire, il apparaît que les RP et RE provoquent l'une et l'autre un grandissement accru des cellules de la peau, l'agent le plus efficace étant la RP ( +25 p. Ioo en moyenne pour la RP et + I2 p. Ioo pour la RE). Toutefois ces différences de taille de cellules ne se réflètent pas au plan des contenus cellulaires en protéines, qui ne diffèrent pas selon le mode de restriction ; ces contenus protéiques des cellules $\mathrm{RP}$ et $\mathrm{RE}$ sont cependant de $\mathrm{I} 2 \mathrm{p}$. Ioo supérieurs à ceux des cellules normales.

La RP n'influence pas le rapport RNA/DNA, cependant que la RE l'augmente sensiblement.

\section{TABLEAU 5}

Peau. - Effets comparés des restrictions protéiques et énergétiques sur diverses caractéristiques de la peau.

en particulier sur les contenus en protéines et en acides nucléiques

A. - Données exprimées en valeur absolue

\begin{tabular}{|c|c|c|c|c|c|c|}
\hline & $\mathrm{T} 70^{*}$ & $\mathrm{~T} 200 *$ & RPM * & $\mathrm{RPF}$ * & REM * & REF * \\
\hline Poids frais $(g) .$. & 8,9 & 33,0 & 33,8 & 31,8 & 34,3 & 34,2 \\
\hline Poids frais $/ 100$ poids vif. & 13,0 & 16,3 & 16,6 & 15,9 & 17,1 & 17,1 \\
\hline Poids SD $(\mathrm{g}) * * \ldots \ldots \ldots$ & 2,23 & 9,24 & 8,96 & 8,36 & $\mathbf{9 , 9 1}$ & 10,60 \\
\hline Poids SD $/ 100$ poids frais & 25,1 & 28,0 & 26,5 & 26,3 & 28,9 & 31,0 \\
\hline DNA/g SD ( $\mu$ M-bases) & 26,0 & 16,6 & 13,5 & 14,4 & 14,1 & 13,5 \\
\hline DNA total ( $\mu$ M-bases). & 58,0 & 153 & 121 & 120 & 140 & 143 \\
\hline RNA/g SD ( $\mu$ M-bases) . & 29,9 & 19,7 & 17,4 & 16,8 & 18,3 & 19,2 \\
\hline RNA total ( $\mu$ M-bases) & 66,7 & 182 & 156 & 140 & 181 & \\
\hline Protéines totales $(\mathrm{g})$.. & 2,02 & 8,44 & 7,99 & 7,58 & 8,90 & 9,45 \\
\hline Poids frais (mg)/DNA ( $\mu$ M-bases) & 153 & 216 & 279 & 265 & 245 & 239 \\
\hline Protéines (mg)/DNA ( $\mu$ M-bases) & 34,9 & 55,2 & 66,0 & 63,2 & 63,6 & 66,1 \\
\hline DNA/RNA $\ldots \ldots \ldots \ldots \ldots$ & 1,15 & 1,19 & 1,29 & 1,17 & 1,30 & 1,42 \\
\hline
\end{tabular}

B. - Données exprimées en p. 100 du lot témoin $200 \mathrm{~g}$ (T 200)

\begin{tabular}{|c|c|c|c|c|c|c|}
\hline & T 70 & T 200 & RPM & RPF & REM & REF \\
\hline Poids frais ... & 27,0 & 100 & 102,4 & 96,4 & 103,9 & 103,6 \\
\hline Protéines totales............ & 23,9 & 100 & 94,7 & 89,8 & 105,4 & 112,0 \\
\hline DNA total.... & 37,9 & 100 & 79,1 & 78,4 & 91,5 & 93,5 \\
\hline RNA total. & 36,6 & 100 & 85,7 & 76,9 & 99,4 & 112,1 \\
\hline
\end{tabular}

* T 70 : Témoin $70 \mathrm{~g}$; T 200 : Témoin $200 \mathrm{~g}$; RPM : Réduction protéique modérée ; RPF : Réduction protéique forte; REM : Réduction énergétique modérée; REF : Réduction énergétique forte. ** SD : Sec et dégraissé. 
D. - Tissus adipeux (tab1. 6)

La quantité des dépôts adipeux est fortement accrue par la RP, et d'autant plus que le taux protéique de la ration est plus faible. Ainsi la quantité de tissus adipeux est fortement augmentée $(+25 \mathrm{p}$. roo) lorsque le régime ne contient que $8 \mathrm{p}$. roo de protéines, et beaucoup plus encore $(+42 \mathrm{p}$. Ioo) pour un régime à $6 \mathrm{p}$. Ioo de protéines. En contraste, la RE inhibe fortement l'accumulation des dépôts adipeux : la réduction est déjà considérable $(-34$ p. Ioo) dans le cas de la restriction énergétique modérée, et elle est encore accentuée (- $-4 \mathrm{I}$ p. Ioo) dans le cas de la restriction énergétique forte. De même, mais dans une moindre mesure, la RP aug-

\section{TABLEAU 6}

Tissus adipeux. - Effets comparés des restrictions protéiques et énergétiques sur diverses caractéristiques des tissus adipeux, en particulier sur les contenus en protéines et en acides nucléiques

\section{A. - Données exprimées en valeur absolue}

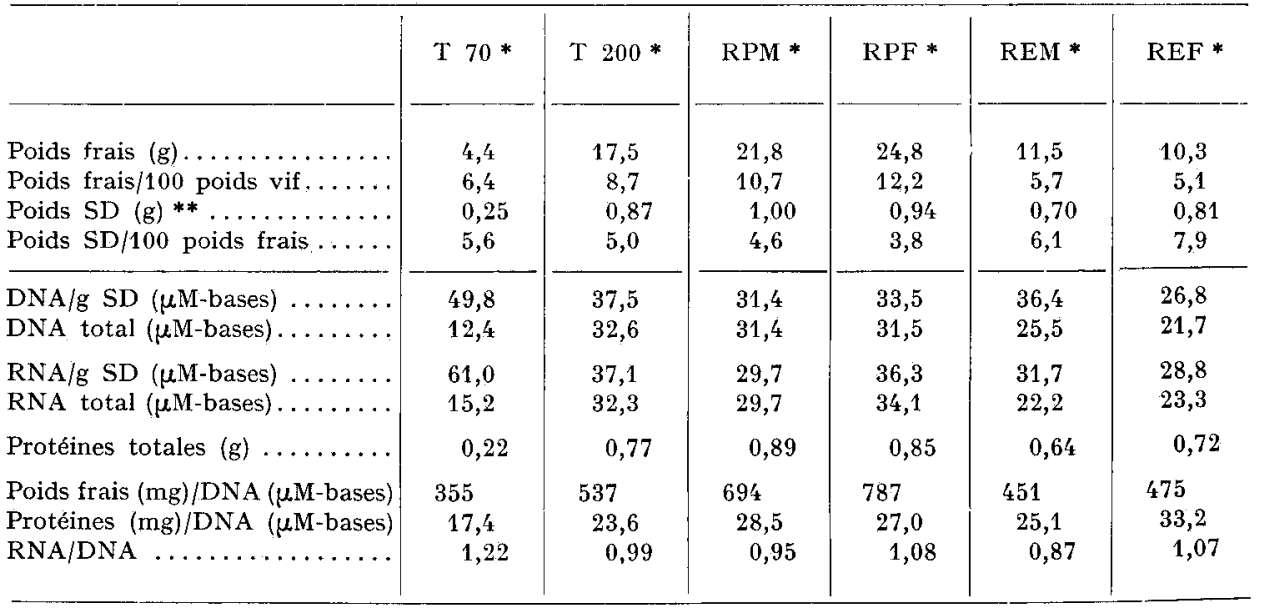

B. - Données exprimées en p. 100 au lot témoin $200 \mathrm{~g}(\mathrm{~T} 200)$

\begin{tabular}{|c|c|c|c|c|c|c|}
\hline & T 70 & $\mathrm{~T} 200$ & RPM & RPF & REM & REF \\
\hline Poids frais $\ldots \ldots \ldots$ & 25,1 & 100 & 124,6 & 141,7 & 65,7 & 58,8 \\
\hline Protéines totales........... & 28,6 & 100 & 115,6 & 110,4 & 83,1 & 93,5 \\
\hline 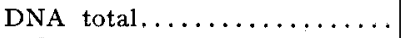 & 38,1 & 100 & 96,3 & 96,6 & 78,2 & 66,6 \\
\hline 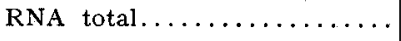 & 47,0 & 100 & 91,9 & 105,6 & 68,7 & 72,1 \\
\hline
\end{tabular}

* T 70 : Témoin $70 \mathrm{~g} ; \mathrm{T} 200$ : Témoin $200 \mathrm{~g}$; RPM : Réduction protéique modérée ; RPF : Réduction protéique forte ; REM : Réduction énergétique modérée ; REF : Réduction énergétique forte.

** SD : Sec et dégraissé. 
mente le contenu protéique des tissus adipeux (de + Io à + I5 p. Ioo), tandis que la RE le diminue (de - 7 à - I7 p. IOo). La quantité de DNA n'est pratiquement pas modifiée par les RP, tandis qu'elle est considérablement amoindrie par la REM (- 22 p. roo) et bien davantage par la REF (- 33 p. Ioo).

Les deux modèles de restriction alimentaire influent dans 1'ensemble sur les quantités de RNA comme sur celles de DNA, si ce n'est que dans le cas de la RE, l'effet de la sévérité du traitement disparaît.

La taille des cellules est considérablement accrue par la RP (de $+29 \mathrm{p}$. roo et $+46 \mathrm{p}$. Ioo suivant le taux protéique), tandis qu'elle est assez modérément réduite par la RE (- I6 p. Ioo et - I2 p. IOo). Les contenus protéiques moyens des cellules des tissus adipeux sont augmentés dans tous les cas; cependant, les contenus en RNA sont généralement peu modifiés par rapport aux témoins, comme l'indique le rapport RNA/DNA dont la valeur varie relativement peu autour de $r$.

\section{E. - Viscères (tabl. 7)}

Le poids frais de l'ensemble hétérogène rassemblé sous la dénomination de viscères est légèrement amoindri par la RP, et au contraire, un peu favorisé par la RE. Il en va de même pour la quantité de protéines contenue dans cette fraction corporelle. Les quantités de DNA sont diminuées sous l'effet de la RP, et relativement moins par la RE. Toutefois ces diminutions n'excèdent guère - Io $\mathrm{p}$. Ioo.

Les quantités de RNA suivent approximativement la même ligne que les protéines : elles sont amoindries par la RP (- I5 p. IOo), et accrues par la RE (+ I7 et + I2 p. roo).

Pour un ensemble comprenant autant d'organes divers, sans compter les contenus digestifs, l'examen des rapports poids frais/DNA, protéines/DNA et RNA/DNA ne peuvent pas être considérés comme des caractéristiques cellulaires et ne seront pas analysés.

$$
\text { F. - Carcasse (tabl. 8) }
$$

Comme nous l'avons vu plus haut, la carcasse est essentiellement constituée du squelette et de la plus grande part de la musculature.

Il apparait qu'aucun des deux types de restriction n'a d'effet signifiant sur le poids de carcasse. La RP n'a pas plus d'effet sur le contenu protéique ; cependant, la RE possède une action favorable $(+4 \mathrm{p}$. Ioo et $+\mathrm{r} 2 \mathrm{p}$. IOo).

Au plan des acides nucléiques, les deux modes de restriction réduisent les quantités de DNA de façon très comparable (de - Io p. Ioo à - I5 p. IOo). Le RNA est assez durement touché par la RP (-23 p. IOo), mais dans une moindre mesure par la RE (- I4 p. IOO).

Les effets constatés semblent peu dépendants de la sévérité des restrictions.

De même que les viscères, la carcasse ne donnera pas lieu à l'analyse de caractéristiques cellulaires.

$$
\text { G. - Animal entier (tabl. 9) }
$$

Le contenu protéique total du corps des Rats parvenus au poids de $200 \mathrm{~g}$ en ayant reçu un régime pauvre en protéines, est amoindri (de -5 à - I2 p. Ioo), tandis qu'il est accru chez les animaux dont l'apport calorique a été restreint 
(+6 p. roo). Ces résultats sont en accord avec ceux qui ont été obtenus au cours de travaux antérieurs (DURAND et coll., I966; DURAND et coll., I967).

La quantité globale de DNA est diminuée aussi bien par la restriction protéique que par la restriction énergétique et à peu près dans les mêmes proportions (de $-8 \mathrm{p}$. IOO à - I4 p. IOO).

\section{TABLEAU 7}

Viscères. - Effets comparés des vestrictions protéiques et énergétiques sur diverses caractéristiques de l'ensemble des viscères, en particulier sur les contenus en protéines et en acides nucléiques

A. - Données exprimées en valeur absolue

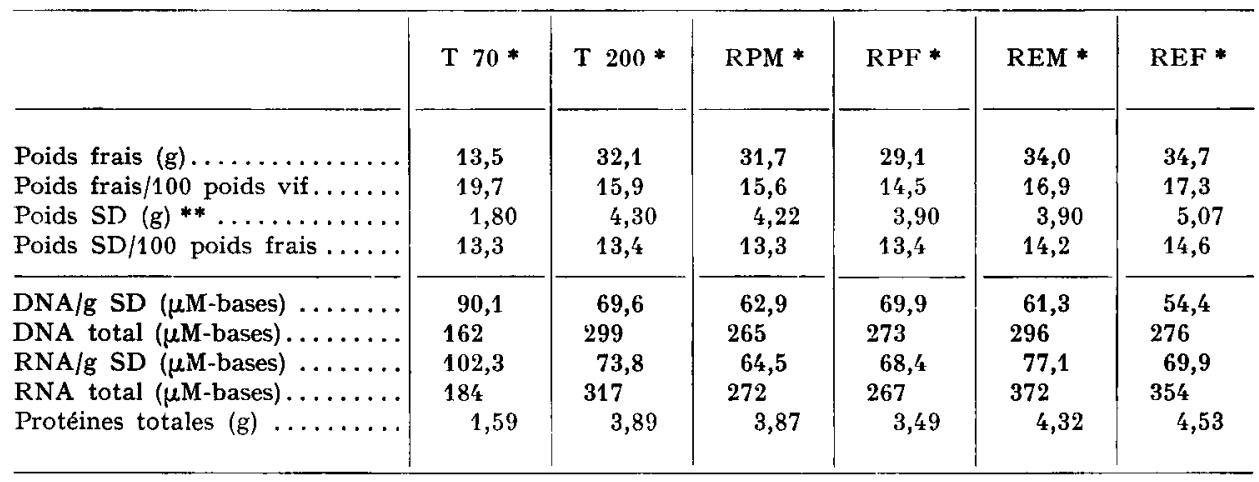

B. - Données exprimées en p. 100 du lot témoin $200 \mathrm{~g}$ ( $\mathrm{T} 200)$

\begin{tabular}{|c|c|c|c|c|c|c|}
\hline & T 70 & T 200 & RPM & RPF & REM & REF \\
\hline Poids frais & 42 & 100 & 98,7 & 90,6 & 105,9 & 108,1 \\
\hline Protéines totales............ & 40,9 & 100 & 99,5 & 89,7 & 111,1 & 116,4 \\
\hline DNA total.......... & 54,2 & 100 & 88,6 & 91,3 & 99,0 & 92,3 \\
\hline RNA total $\ldots \ldots \ldots \ldots \ldots \ldots$ & 58,0 & 100 & 85,8 & 84,2 & 117,3 & 111,7 \\
\hline
\end{tabular}

* T 70 : Témoin $70 \mathrm{~g} ; \mathrm{T} 200$ : Témoin $200 \mathrm{~g} ; \mathrm{RPM}$ : Réduction protéique modérée; RPF : Réduction protéique forte ; REM : Réduction énergétique modérée; REF : Réduction énergétique forte.

** SD : Sec et dégraissé.

Il en va différemment pour la quantité globale de RNA, très amoindrie par la restriction protéique (-20 p. IOo), mais très peu touchée par la restriction énergégétique (- 4 p. roo).

Pour un type de restriction donnée, il faut remarquer que la limitation de la vitesse de croissance, ou à la moitié, ou au tiers de la vitesse de croissance des témoins, n'est pas suivie d'effets nettement différents quant aux diverses caractéristiques étudiées. 
Carcasse. - Effets comparés des restrictions protéiques et énergétiques sur diverses caractéristiques de la carcasse (musculature + squelette), en particulier sur les contenus en protéines et en acides nucléiques

A. - Données exprimées en valeur absolue

\begin{tabular}{|c|c|c|c|c|c|c|}
\hline & $\mathrm{T} 70 *$ & $\mathrm{~T} 200 *$ & $\mathrm{RPM} *$ & RPF * & REM* & REF * \\
\hline Poids frais $(g) \ldots \ldots$ & 31,4 & 89,0 & 87,4 & 84,5 & 89,7 & 89,6 \\
\hline Poids frais $/ 100$ poids vif. & 45,9 & 44,0 & 43,0 & 42,2 & 44,6 & 44,7 \\
\hline Poids $\mathrm{SD}(\mathrm{g}) * * \ldots \ldots \ldots \ldots$ & 5,50 & 17,0 & 17,4 & 17,0 & 17,9 & 19,1 \\
\hline Poids SD $/ 100$ poids frais ..... & 17,4 & 19,2 & 19,9 & 20,1 & 20,0 & 21,3 \\
\hline DNA/g SD ( $\mu$ M-bases) & 37,7 & 19,8 & 16,5 & 17,4 & 17,1 & 15,0 \\
\hline DNA total ( $\mu$ M-bases)..... & 207 & 337 & 287 & 296 & 306 & 286 \\
\hline RNA/g SD ( $\mu$ M-bases) & 43,6 & 23,3 & 17,7 & 17,7 & 19,0 & 17,9 \\
\hline RNA total ( $\mu$ M-bases) . & 240 & 396 & 309 & 309 & 340 & 342 \\
\hline Protéines totales $(\mathrm{g}) \ldots$ & 4,9 & 15,4 & 15,9 & 15,1 & 16,0 & 17,2 \\
\hline
\end{tabular}

B. - Données exprimées en p. 100 du lot témoin $200 \mathrm{~g}$ ( T 200)

\begin{tabular}{|c|c|c|c|c|c|c|}
\hline & T 70 & T 200 & RPM & $\mathrm{RPF}$ & REM & REF \\
\hline Poids frais $\ldots \ldots \ldots \ldots \ldots \ldots$ & 35,3 & 100 & 98,2 & 94,9 & 100,8 & 100,7 \\
\hline Protéines totales........... & 31,8 & 100 & 103,2 & 98,0 & 103,9 & 111,7 \\
\hline DNA total............. & 61,4 & 100 & 85,2 & 87,8 & 90,1 & 84,9 \\
\hline RNA total............ & 60,6 & 100 & 78,0 & 76,0 & 85,8 & 86,4 \\
\hline
\end{tabular}

* T 70 : Témoin $70 \mathrm{~g}$; T 200 : Témoin $200 \mathrm{~g}$; RPM : Réduction protéique modérée ; RPF : Réduction protéique forte; REM : Réduction énergétique modérée; REF : Réduction énergétique forte. ** SD : Sec et dégraissé.

\section{TABLEAU 9}

\section{Corps entier}

Contenus en protéines et en acides nucléiques du corps entier des rats des divers lots

\begin{tabular}{|c|c|c|c|c|c|c|}
\hline & $\mathrm{T} 70^{*}$ & $\mathrm{~T} 200^{*}$ & RPM * & RPF * & REM * & REF * \\
\hline $\begin{array}{l}\text { Protéines totales }(g) \ldots \ldots \ldots \ldots \\
\text { (T } 200 \text { p. 100) } \ldots \ldots \ldots \ldots \ldots\end{array}$ & $\begin{array}{c}10,0 \\
(28,9)\end{array}$ & $\begin{array}{r}34,5 \\
(100)\end{array}$ & $\begin{array}{c}32,8 \\
(94,8)\end{array}$ & $\begin{array}{c}31,1 \\
(89,9)\end{array}$ & $\begin{array}{c}36,6 \\
(105,8)\end{array}$ & $\begin{array}{c}36,8 \\
(106,3)\end{array}$ \\
\hline $\begin{array}{l}\text { DNA total }(\mu \text { M-bases }) \ldots \ldots \ldots \\
(\text { T } 200 \text { p. } 100) \ldots \ldots \ldots \ldots \ldots\end{array}$ & $\begin{array}{l}480 \\
(52,4)\end{array}$ & $\begin{array}{c}915 \\
(100)\end{array}$ & $\begin{array}{l}784 \\
(85,7)\end{array}$ & $\begin{array}{l}798 \\
(87,2)\end{array}$ & $\begin{array}{l}846 \\
(92,4)\end{array}$ & $\begin{array}{l}802 \\
(87,6)\end{array}$ \\
\hline $\begin{array}{l}\text { RNA total }(\mu \text { M-bases }) \ldots \ldots \ldots \\
(T 200 \text { p. } 100) \ldots \ldots \ldots \ldots\end{array}$ & $\begin{array}{l}609 \\
(51,9)\end{array}$ & $\begin{array}{r}1174 \\
(100)\end{array}$ & $\begin{array}{l}959 \\
(81,7)\end{array}$ & $\begin{array}{l}937 \\
(79,8)\end{array}$ & $\begin{array}{ll}1 & 129 \\
& (96,1)\end{array}$ & $\begin{array}{l}1124 \\
\quad(95,7)\end{array}$ \\
\hline
\end{tabular}

* T 70 : Témoin $70 \mathrm{~g} ; \mathrm{T} 200$ : Témoin $200 \mathrm{~g}$; RPM : Réduction protéique modérée ; RPF : Réduction protéique forte; REM : Réduction énergétique modérée; REF : Réduction énergétique forte. 


\section{DISCUSSION}

Dans la plupart des travaux relatifs aux effets des carences alimentaires, les sujets expérimentaux sont comparés à des témoins de même âge. Cependant, à bien des égards, la physiologie des animaux, et plus particulièrement celle des mammifères, est liée à leur poids ; partant, ce dernier est l'un des critères fréquemment utilisé pour la détermination de l'âge biologique. A cet aspect biologique, qui met en relief l'importance du poids vif, vient s'ajouter l'aspect économique, lorsqu'il s'agit d'animaux domestiques. C'est pourquoi nous avons comparé ici les expérimentaux à des témoins de poids égal, plutôt qu'à des témoins de même âge chronologique.

Il ressort des résultats exposés précédemment que, pour les deux types de restrictions étudiés, les effets constatés varient peu ou pas selon la sévérité de la restriction.

Aussi, dans la discussion, n'est-il pas fait état de la rigueur du régime. Une récapitulation, sous forme de symboles, des principaux résultats de ce travail, est portée sur le tableau Io.

\section{A. - Muscles}

Il ressort des résultats que les Rats soumis à restriction énergétique après sevrage possèdent une musculature plus volumineuse, contenant davantage de protéines, mais moins de DNA et RNA que des témoins de même poids ; les valeurs des rapports poids frais/DNA et protéines/DNA sont plus élevées chez les restreints, tandis que la valeur du rapport RNA/DNA est, par contre, conservée. Ces conclusions confirment celles d'une précédente publication (DuRAND et al., I967), à cette différence près que le rapport RNA/DNA était légèrement diminué chez les Rats restreints. De même, Elimot' et CheEk (Ig68), GRaystone et ChEEK (I969), HiLi, et coll. (I970) trouvent que le rapport protéines/DNA est augmenté et que le rapport RNA/DNA n'est pas modifié dans la musculature de Rats restreints en calories comparés à des témoins de mêtne âge. De plus, CHEEK et HILL (I970) montrent que le rapport protéines/DNA est augmenté par la restriction calorique, lorsque la comparaison est faite à poids égal de muscle. Enn revanche, WINICK et NoBLE (I966) indiquent une diminution de ce rapport chez des Rats carencés en énergie comparés à des témoins de même âge ; mais, comme le soulignent HII, et coll. (I970), l'apport protéique de la ration n'est pas précisé et les animaux étaient, semble-t-il, soumis à la double carence protéines-calories.

ARNal et coll. (I972) montrent que, chez des Rats soumis à une réduction de 50 p. roo de l'apport énergétique de la ration, la synthèse protéique dans les muscles, mesurée par la vitesse d'incorporation de L-1ysine- ${ }^{14} \mathrm{C}$, est ralentie de $40 \mathrm{p}$. IOO, tandis que le catabolisme est ralenti de $25 \mathrm{p}$. Ioo ; ces auteurs calculent que, dans ces conditions, le temps moyen de renouvellement des protéines musculaires passe de 7,5 à I6, I jours. Dans ce cas de carence énergétique, i1 n'y a donc pas parallèlisme entre l'évolution de l'anabolisme protéique réel et la valeur du rapport RNA/DNA puisque la valeur de ce dernier est conservée ; dans le cas étudié, le rapport RNA/protéines semble être un meilleur critère de l'intensité de la synthèse protéique.

La restriction protéique ne modifie ni le poids frais, ni le contenu protéique de 
la musculature ; elle diminue cependant le contenu en acides nucléiques : le DNA dans la même proportion que la carence énergétique, et le RNA sensiblement plus. Finalement, les rapports poids frais/DNA et protéines/DNA sont plus élevés que chez les témoins, sans atteindre toutefois les valeurs mesurées chez les restreints énergétiques, tandis que le rapport RNA/DNA est sensiblement diminué.

Plusieurs auteurs ont étudié les effets de l'insuffisance de l'apport protéique de la ration sur la musculature, en comparant les animaux à des témoins de même âge, c'est-à-dire plus lourds : MENDES et WATERLOW (I958) concluent à une diminution du rapport protéine/DNA dans les muscles de Rats qui reçoivent des régimes à bas taux protéiques. STRUNZ et LENKEIT (I963) trouvent que les muscles de Porcelets carancés en protéines se caractérisent par un contenu en DNA plus faible, et des rapports protéines/DNA et RNA/DNA amoindris. De même HILL et coll. (I970) constatent que chez des Rats recevant un régime à $6 \mathrm{p}$. Ioo de caséine, la quantité de DNA dans le muscle et le rapport protéine/DNA sont significativement moindres que chez des témoins de même âge. Par contre, HowarTH (I972) montre que lors d'une carence protéique, la synthèse protéique a priorité sur la synthèse du DNA, avec pour conséquence un rapport protéines/DNA inchangé.

Par ailleurs, WATERL,ow et STEPHEN (I968) concluent que la durée moyenne de ranouvallement des protéines musculaires est doublé à la suite d'une réduction de l'apport protéique de la ration, ce qui, compte tenu des résultats de ARNAI et coll. (I972) laisse apparaître une certaine similitude entre les effets respectifs des carences protéique et énergétique quant à la physiologie musculaire.

En résumé, il rassort de l'ensemble de ces résultats que des carences soit énergétiques, soit protéiques, provoquant un ralentissement comparable de la vitesse de croissance, ont un effet dépressif à peu près équivalent sur l'accumulation de DNA dans la musculature; l'accumulation de RNA est freinée par les deux types de carance, mais plus particulièrement par la carence protéique, de sorte que le rapport RNA/DNA, peu modifié par la carence énergétique, est franchement amoindri par la carence protéique. Enfin, si la grande majorité des auteurs s'accordent à reconnaître un effet majorant de la restriction énergétique sur le rapport protéines/DNA, un doute pourrait subsister quant à l'effet de la restriction protéique ; cela tient vraivraisemblablement au choix des témoins qui sont tantôt de même âge, tantôt de même poids : ainsi on peut penser que la carence protéique est ou minorante ou majorante, suivant que la comparaison est établie entre animaux restreints et témoins ou de mêtme âge ou de même poids.

Sur un autre plan, CHEEk et HILL (I970) évoquent le rôle, d'une part de l'hormone somatotrope sur le contrôle de la synthèse du DNA, donc de la multiplication cellulaire, d'autre part de l'insuline sur le contrôle de la valeur du rapport protéines/DNA, donc de la taille des cellules. Ces auteurs émettent l'hypothèse suivant laquelle 1'apport calorique de la ration influencerait l'activité de 1'hormone somatrotrope, qui agirait sur la multiplication cellulaire, tandis que 1'apport protéique influencerait la sécrétion d'insuline, qui agirait sur la taille des cellules.

Dans le cas de carence énergétique avec apport protéique normal, nos résultats - rapport protéines/DNA augmenté, contenu en DNA réduit - viennent bien à l'appui de cette hypothèse ; mais dans le cas de carence protéique, elle n'est confirmée ni par nos résultats, ni par ceux de HowarTH (r972) qui montrent que, dans le muscle, la carence protéique agit dans le même sens que la carence énergétique. 


\section{B. - Foie}

Les résultats issus de cette expérience indiquent que la restriction énergétique n'a qu'un effet modéré sur la diminution de la taille du foie. Cela semble en contradiction avec des précédentes conclusions (DURAND et al., I967) qui font apparaître, dans des conditions expérimentales comparables, un écart de près de $30 \mathrm{p}$. Ioo entre le poids frais du foie de Rats témoins et restreints : cela est dû au fait que, dans le précédent travail, les animaux restreints, qui consomment leur ration en quelques heures, étaient à jeun au moment du sacrifice, tandis que les témoins ne l'étaient pas.

De la même façon, la restriction énergétique n'a pratiquement pas d'influence sur le contenu protéique du foie. Par contre, elle limite considérablement l'accumulation du DNA hépatique. Ainsi, le rapport poids frais/DNA comme le rapport protéines/DNA sont plus élevés dans le foie des restreints. Ces observations sont en accord avec celles de Graystone et CheEK (I969), Erliotot et ChEEK (I968) qui constatent une réduction du DNA total et une augmentation du rapport protéines/DNA dans le foie de Rats ne recevant que 50 p. Ioo d'un apport calorique normal, mais des protéines en quantité suffisante. Cependant ces auteurs comparant les animaux expérimentaux à des témoins de même âge, donc plus lourds, il n'est pas surprenant que le foie des premiers soit de taille inférieure et moins riche en DNA que celui des seconds; par contre l'accroissement, dans les mêmes conditions, du rapport protéines/DNA est particulièrement significatif. Les mêmes remarques peuvent s'appliquer aux observations de HIL, et coll. (I970).

Par ailleurs, la quantité totale de RNA est amoindrie par le manque de calories, mais toutefois moins que la quantité totale de DNA, de sorte que le rapport RNA/DNA est légèrement plus élevé chez les restreints que chez les témoins. Des publications antérieures (DURAND et al., I967; HIL 1 et coll., I970) font apparaître au contraire un rapport RNA/DNA légèrement diminué ; quoi qu'il en soit, comme nous le verrons ci-dessous, l'insuffisance de l'apport énergétique agit bien moins sur le rapport RNA/DNA que ne le fait la carence protéique. Cette dernière en effet réduit fortement le poids frais du foie, de même que les contenus de cet organe en protéines et en acides nucléiques ; en comparaison avec la carence énergétique, la réduction est moins marquée pour le DNA et plus marquée pour le RNA. Il en résulte que les rapports poids frais/DNA, protéines/DNA et RNA/DNA sont plus bas que la normale dans les foies des animaux restreints en protéines, alors qu'ils sont plus élevés chez les restreints en énergie.

Ces observations relatives aux effets de l'insuffisance de l'apport protéique de la ration sont en bon accord avec celles de MENDES et WATERLow (I958) et DURAND et coll. (I966). En outre, contrairement à ce qu'il en est pour la musculature, les phénomènes observés au plan hépatique concernant les effets comparés restriction protéique-restriction calorique, peuvent s'insérer dans le cadre de la théorie de CHEEK et HILI (I970) dont il est question plus haut.

Par ailleurs, la baisse du rapport RNA/DNA n'interdit pas un accroissement de la synthèse protéique vraie (VANDERMEERS et coll., I967), ni un renouvellement plus rapide des divers types de RNA (QUIRIN-STRICker et MANDEL, I968).

Enfin, il faut rappeler que tous les facteurs qui ralentissent la croissance générale de 1'organisme peuvent agir sur la polyploïdie hépatique (NADAL, et ZAJDELA, I965). I1 serait donc risqué de transposer les quantités de DNA en nombre de cellules. 


\section{C. - Peau}

Chez un animal de petite taille, la peau constitue un compartiment corporel très important : elle représente, chez un Rat de $200 \mathrm{~g}, \mathbf{I} 6 \mathrm{p}$. Ioo du poids vif, et contient environ $25 \mathrm{p}$. Ioo des protéines corporelles. Elle supporte bien un retard de croissance dû à une insuffisance de l'alimentation calorique, puisqu'à poids corporel égal, la peau des restreints est aussi lourde, plus riche en protéines, à peine plus pauvre en DNA que celle des témoins ; elle présente en outre des rapports protéines/DNA et RNA/DNA augmentés. Lorsque la sous-alimentation énergétique est assez sévère pour arrêter la croissance, la peau perd un nombre important de cellules (DuRAND et PENot, I970). Cependant, lors du retour à des conditions alimentaires normales, la capacité de récupération est excellente.

Par ailleurs, ARNAI et coll. (r972) constatent que lorsqu'un ralentissement de croissance est provoqué par une sous-nutrition calorique, la synthèse et le catabolisme des protéines sont ralentis, et le temps de renouvellement de celles-ci est augmenté. Mais, comme pour le muscle, nos résultats montrent que ces phénomènes ne sont accompagnés ni d'une diminution du rapport RNA/DNA au contraire légèrement augmenté, ni du rapport RNA/protéines, pratiquement inchangé.

Dans le cas de sous-nutrition protéique appliquée à de jeunes rats, WATERLOW et STEPHEN (I966) montrent que la peau et.la fraction corporelle ou le manque à gagner est le plus important.

\section{D. - Tissus adipeux}

Les tissus adipeux sont, comme on peut s'y attendre, les plus sensibles à la sous-nutrition énergétique. La quantité de DNA qu'ils contiennent, ainsi que le rapport poids frais/DNA, se trouvent fortement réduits chez les animaux restreints en calories. Par contre, le rapport protéines/DNA est augmenté, ce qui suggère qu'il n'est pas toujours le mieux adapté pour évaluer la taille des cellules; le rapport RNA/DNA reste inchangé. Lorsque la sous-nutrition calorique, appliquée à la Ratte adulte est assez importante pour provoquer une perte de poids vif de $-28 \mathrm{p}$. Ioo (Durand et Penot, I969 $b$ ), les tissus adipeux perdent 38 p. Ioo de leur contenu en DNA, tandis que le rapport poids frais/DNA est diminué de moitié et les rapports protéines/DNA et RNA/DNA sont peu modifiés. DesNoyers et coll. (sous presse) observent que, dans le cas d'amaigrissement très important, les adipocytes parvenus à maturité disparaissent, alors que les adipocytes en cours de maturation se vident de la plus grande part de leurs lipides, tout en conservant intact l'ensemble des structures cellulaires.

Par ailleurs, Peckham et coll. (I962) montrent qu'un régime hypercalorique stimule la synthèse de DNA dans le tissu adipeux épididymaire du Rat; mais la cellularité des tissus adipeux peut varier non seulement en fonction de l'apport énergétique, mais aussi en fonction de la nature des éléments énergétiques de la ration (Raulin et Launay, I967 ; Launay et coll., I968 ; Kazdova et coll., i968), et du rythme des repas (BRAUn et coll., I965).

La sous-nutrition protéique est bien connue pour accroître le volume des dépôts adipeux ; toutefois les résultats présentés ici montrent que la quantité totale de DNA, 
de même que la quantité de RNA, sont équivalentes chez les témoins et les Rats carencés en protéines.

Ainsi hypernutrition calorique et sous-nutrition protéique sont suivies l'une et 1'autre d'une hypertrophie des tissus adipeux ; cette dernière résulte en même temps de 1'hypertrophie et de 1'hyperplasie cellulaires lorsque la ration est hyperénergétique, mais uniquement de 1'hypertrophie cellulaire lorsque la ration est hypoprotéique.

\section{E. - Viscères}

L'examen d'un ensemble aussi hétérogène que ce qui est rassemblé sous le terme de "viscères " est délicat. On remarquera cependant qu'en poids, il est certainement constitué pour plus de la moitié par le tube digestif; de même on peut penser que ce dernier apporte les $2 / 3$ des acides nucléiques de l'ensemble, puisque l'intestin grêle à lui seul apporte environ Ioo $\mu \mathrm{M}$-bases de DNA et I20 $\mu \mathrm{M}$-bases de RNA (DURAND et coll., I965-I966) sur, respectivement, $300 \mu \mathrm{M}$-bases de DNA et $320 \mu \mathrm{M}$-bases de RNA contenues dans la totalité de la fraction. Quoi qu'il en soit, celle-ci n'est pas particulièrement sensible à la restriction énergétique : en effet, bien que légèrement désavantagée pour le contenu en DNA, elle contient davantage de protéines et de RNA que la fraction correspondante de témoins de même poids. Il faut remarquer à ce propos que les animaux soumis à une restriction de l'apport calorique, ingèrent leur ration rapidement après sa distribution et pratiquement en un seul repas; dans ces conditions, la digestion est lente (RoGERs et HARPER, Ig66) ; il en résulte pendant plusieurs heures par jour une distension stomacale et un fonctionnement digestif prolongé, qui sont susceptibles de stimuler, à travers une modification du rythme physiologique, certains aspects du métabolisme du tube digestif. La restriction protéique, en revanche, manifeste un effet dépressif sur tous ces points.

Par ailleurs, ARNAL et coll. (I972) montrent que contrairement à ce qui est observé dans le muscle et la peau, la malnutrition calorique stimule la synthèse et le catabolisme dans la partie corporelle composée des viscères abdominaux; ces auteurs, rapprochant leurs résultats de ceux de VANDERMEERs et coll. (I967) et de STEPHEN et WATERLOW (I966) remarquent des analogies entre les effets des deux types de carence, en ce qui concerne la synthèse protéique. Toutefois, au plan des diverses caractéristiques étudiées dans le présent travail, apparaissent des différences qui laissent à penser que les effets des deux types de restriction ne peuvent pas être superposés.

Ajoutons encore que le groupe d'organes étudié par ARNAL et coll. comporte le foie, alors que nous traitons celui-ci séparément. Compte tenu de l'importance pondérale et métabolique de cet organe, il peut en résulter des écarts considérables.

\section{F. - Carcasse}

Cette dernière est constituée essentiellement par la musculature et le squelette.

En cas de sous-nutrition protéique, le poids frais et le contenu protéique de la carcasse ne sont pratiquement pas modifiés ; il en est de même pour la musculature des membres postérieurs. En cas de sous-nutrition calorique, le poids frais et le contenu protéique de la carcasse sont égaiement peu modifiés, contrairement aux mêmes éléments de la musculature, qui se trouvent augmentés. 
Par ailleurs, les deux types de carence alimentaire diminuent respectivement, dans les mêmes proportions, les contenus en acides nucléiques de la carcasse et de l'ensemble musculaire considéré.

\section{G. - Animal entier}

En effectuant la somme des résultats obtenus pour chacune des fractions étudiées, on reconstitue " l'animal entier ». Il apparaît que les effets respectifs des deux types de restriction sur chaque organe ou tissu se compensent et que l'examen des effets globaux ne fournit qu'une image assez vague des réalités ponctuelles. On relève pourtant quelques lignes directrices : la carence énergétique augmente le contenu en protéines de l'organisme, la carence protéique le diminue; les deux types de restrictions diminuent la quantité de DNA de l'organisme dans la même proportion ; la différence la plus sensible concerne le contenu en RNA, peu modifié par la sous-nutrition calorique, mais très franchement amoindri par la carence protéique.

\section{TABLEAU IO}

Contenus en protéines et en acides nucléiques des tissus et organes de Rats dont la croissance est ralentie soit par restriction protéique (RP), soit par vestriction énergétique (RE), comparés aux contenus correspondants de Rats témoins de même poids

Poids vif initial : $70 \mathrm{~g}$; poids vif final : $200 \mathrm{~g}$; vitesse de croissance des témoins : $6 \mathrm{~g} / \mathrm{jour}$; vitesse de croissance des deux types de restreints : $2, \mathrm{I}$ g/jour.

Les symboles indiquent que les écarts, positifs ou négatifs, entre témoins et restreints sont: inférieurs à $5 \mathrm{p}$. Ioo $(=)$; compris entre $5 \mathrm{p}$. Ioo et $20 \mathrm{p}$. Ioo $(+$ et $\longrightarrow$; supérieurs à $20 \mathrm{p}$. I 00 $(++$ et $--1-$.

\begin{tabular}{|c|c|c|c|c|c|c|c|}
\hline & $\begin{array}{l}\text { Muscles } \\
\text { MP (1) }\end{array}$ & Foie & Peau & $\begin{array}{c}\text { Tissus } \\
\text { adipeux }\end{array}$ & Viscères & Carcasse & $\begin{array}{l}\text { Animal } \\
\text { entier }\end{array}$ \\
\hline $\begin{array}{l}\text { Poids } \\
\text { frais }\end{array}\left\{\begin{array}{l}\mathrm{RP} \ldots \ldots \\
\mathrm{RE} \ldots\end{array}\right.$ & $=$ & - & $\begin{array}{l}= \\
=\end{array}$ & $\begin{array}{l}++ \\
--\end{array}$ & - & - & \\
\hline Contenu $\left\{\begin{array}{l}\text { RP.... } \\
\text { protéique }\end{array}\right.$ & $\begin{array}{l}= \\
+\end{array}$ & - & + & + & + & $=$ & - \\
\hline $\begin{array}{c}\text { Contenu } \\
\text { DNA }\end{array}\left\{\begin{array}{l}\text { RP..... } \\
\text { RE } \ldots .\end{array}\right.$ & - & - & - & $\begin{array}{c}= \\
-1\end{array}$ & - & - & - \\
\hline $\begin{array}{c}\text { Contenu } \\
\text { RNA }\end{array}\left\{\begin{array}{l}\text { RP.... } \\
\text { RE .... }\end{array}\right.$ & - & -- & $\frac{--}{+}$ & $\begin{array}{c}+ \\
-\end{array}$ & - & - & - \\
\hline
\end{tabular}

(1) MP : Membres postérieurs.

\section{CONCLUSION}

La comparaison, chez de jeunes Rats de même poids, entre restriction énergétique et restriction protéique, montre que chacun des deux types de tissu ou chaque organe réagit distinctement aux conditions alimentaires imposées. C'est là un nouvel 
exemple de la relative indépendance dont jouissent les divers composants de l'organisme qui, entre autres choses, contrôlent leur prolifération par leurs propres sécrétions (chalones, facteurs de croissance) et répondent distinctement aux impulsions des éléments variés (nutriments, hormones) véhiculés jusqu'à eux par le milieu circulant.

Reçu pour publication en février 1973.

\section{SUMMARY}

COMPARED EFFECTS OF PROTEIN AND ENERGY RESTRICTION

ON THE PROTEIN AND NUCLEIC ACID CONTENT IN GROWING RAT TISSUES.

Either the protein or the calory intake of the ration is restricted in lots of male rats weaned for one week and weighing $70 \mathrm{~g} \pm 3$ on an empty stomach. They are compared to a control lot eating a balanced diet containing $16 \mathrm{p}$. Ioo protein. All the lots are sacrificed when their average bodyweight is $200 \mathrm{~g}$ on an empty stomach.

The rations given to the restricted lots are adjusted as to protein or to calories so that, two by two, the lots present identical average growth $\left(\frac{\mathrm{V}}{2}\right.$ and $\frac{\mathrm{V}}{3}, \mathrm{~V}$ being the average growth rate of the controls).

The bodies of the animals are dissected into six parts : posterior limb musculature ; liver ; skin; adipose tissue ; viscera ; carcass (musculature + skeleton). Fresh weight of the six body fractions is measured as well as protein content, DNA and RNA of these fractions. Cell number and size are estimated from the measurements.

The results show that the effects of the two types of restriction are very variable, depending on the body fraction and the criterium under consideration. Several points stand out :

- Fresh weight: protein restriction enhances adipose tissue, while energy restriction favorizes musculature and viscera

- Protein content : protein restriction enhances adipose tissue, energy restriction the musculature, skin, viscera and carcass.

- DNA content : except for adipose tissue, protein restriction depresses all fractions, and especially the skin, energy restriction depresses all fractions, and especially the liver and adipose tissue.

- RNA content: protein restriction generally reduces the RNA content considerably in the various fractions, except that of the adipose tissue which increases; energy restriction increases RNA content in the skin and viscera.

\section{RÉFÉRENCES BIBLIOGRAPHIQUES}

Arnal M., Fauconneau G., Pech ${ }^{-\cdots}$., I972. Synthèses protéiques in vivo dans divers tissus du Rat en croissance soumis à une réduction de l'apport énergétique de la ration. Ann. Biol. anim. Bioch. Biophys., 12, 91-I08.

Braun T., Kazdova L., FABRy P., Lojda Z., I965. The effect of the frequency of food intake on the protein and nucleic content of Rat adipose tissue. Physiol. Bohemoslovaka (Prague), 14, 559-562.

Cheek D. B., Hill $\quad$ D. E., r970. Muscle and liver cell growth : rôle of hormones and nutritional factors. Federation Proc., 29, I503-I509.

Desnoyers F., Vodovar N., Durand G., 1973. Transformation et devenir des cellules adipeuses au cours de l'amaigrissement. Ann. Biol. anim. Bioch. Biophys. (sous presse). 
Durand G., Fauconneau G., Penot E., 1966. Croissance des tissus du Rat et qualité des protéines alimentaires; influence sur le nombre et la taille des cellules. Ann. Biol. anim. Bioch. Biophys., 6, $3^{89}$ 409.

Durand G., Fauconneau G., Penot E., ig67. Croissance des tissus du Rat et réduction de l'apport énergétique de la ration; influence sur la teneur en acides nucléiques. Ann. Biol. anim. Bioch. Biophys., 7, I45-I 55 .

Durand G., Fauconneau G., Penot E., I968. Évolution des teneuts en acides nucléiques et en protéines dans les tissus du Rat soumis à une carence énergétique sévère et prolongée. Croissance compensatrice. Ann. Biol. anim. Bioch. Biophys., 8, 36r-371.

Durand G., Fauconneau G., Penot E., I 969 a. Répartition des cellules entre les tissus du Rat adulte, préalablement soumis à une sous-nutrition énergétique temporaire à deux stades de la croissance. Ann. Biol. anim. Bioch. Biophys., 9, 55-73.

Durand G., Penot E., I969 $b$. Évolution du nombre et de la taille des cellules dans les tissus de la Ratte adulte amaigrie à la suite d'une carence énergétique. Croissance compensatrice. Ann. Biol. anim. Bioch. Biophys., 9, 575-587.

Durand G., Penot E., I970. Effets du maintien à poids constant pendant de longues durées chez le: Rat sevré. Reprise de la croissance. Ann. Biol. anim. Bioch. Biophys., 10, 385-399.

Elliotr D., Cheek D. B., I968. Muscle cell growth in rats with hypoxia and reduced nitrogen. In : Human growth. Edited by D. R. Cheek, Chap. 23. Lea et Febiger, Philadelphia.

Graystone J. E., Cheek D. B., I969. The effects of reduced caloric intake and increased insulininduced caloric intake on the cell growth of muscle, liver and cerebrum and on skeletal collagen in the postweanling rat. Pediat. Res., 3, 66-76.

Hill D. E., Holt A. B., Parra A., Cheek D. B., r97o. The influence of protein-caloric versus caloric restriction on the body composition and cellular growth of muscle and liver in weanling rats. John's Hopkins med. J., $127,146-163$.

How ARTH R. E. I972. Influence of dietary protein on Rat skeletal muscle growth. J. Nutr., 102, 37-44.

Kazdova L., Fabry P., Braun T., rg68. Composition of diet and response of adipose tissue to refeeding. Physiol. Bohemoslovaka (Prague), 17, 469.

Launay M., Vodovar N., Raulin J., I968. Developpement du tissu adipeux. Nombre et taille des cellules en fonction de la valeur énergétique et de l'insaturation des lipides du régime. Bull. Soc. Chim. biol., 50, 439-450.

Mendes C. B., Waterlow J. C., 1958. The effect of a low-protein diet, and of refeeding on the composition of liver and muscle in the weanling Rat. Brit. J. Nutr., 12, 74-88.

Nadal C., Zajpela F., I966. Polyploïdie dans le foie de Rat. II. Le rôle de l'hypophyse et de la carence protéique. Exptl. Cell Res., 42, II7-I29.

Peckham S. C., Entenman C., Carroll H. W., 1962. The influence of a hypercaloric diet on gross body and adipose tissue composition in the Rat. J. Nutr., 77, 187-197.

Platt B. S., Heard C. R. C., Steward R. J. C., 1964. Experimental protein-caloric deficiency. In : Mammalian protein metabolism. 2, chap. $2 \mathrm{I}$, edited by $\mathrm{H}$. N. Munro et J. B. Allison. Academic Press, Inc., New York.

Quirin-Stricker C., Mandel P., I968. Étude du renouvellement du RNA des polysomes, du RNA de transfert et du RNA "messager " dans le foie de Rat soumis à un jeûne protéique. Bull. Soc. Chim. Biol., 50, $31-45$.

Raulin J., Launay M., 1967. Enrichissement en DNA et RNA du tissu adipeux épididymaire du Rat par administration de lipides insaturés. Nutr. et Dieta, 9, 208-221.

Rogers Q. R., Harper A. E., r966. Protein digestion : nutritional and metabolic considerations. Wld. Rev. Nutr. Diet., 6, 250-291.

Strunz K., LENkeit W., 1963. Die Stickstoff-und Nukleinsäure-Verteilung im Ferkelhörper unter dem Einfluss der Proteinzufuhr. 2. Der DNS- und RNS-Gehalt in Skeletmuskulatur, Herzmusculatur, Niere, Leber und Milz. Z. Tierphys. Tierernähr. Futterm., 18, 285-296.

Vandermeers A., Vandermeers-Piret M.-C., Christophe J., 1967. Synthèses protéiques in vivo dans le pancréas et le foie du Rat normal, carencé en lysine et en thréonine, ou récupérant de cette ca. rence. Bull. Soc. chim. Biol., 49, 759-778.

Waterlow J. C., Stephen J. M., I966. Adaptation of the rat to a low protein diet : the effect of a reduced protein intake on the pattern of incorporation of L-14 C-lysine. Br. J. Nutr., 20, $46 \mathrm{I}-484$.

Waterlow J. C., Stephen J. M., ig68. The effect of low protein diets on the turnover rates of serum, liver and muscles proteins in the rat, measured by continuous infusion of $\mathrm{L}^{14} \mathrm{C}$-lysine. Clin. Sci., 35, 287-305.

Winick M., Noble A., r966. Cellular response in Rats during malnutrition at various ages. J. Nutr., 89, $300-306$. 